\title{
Analisis Torsi Mengikuti Pola Gerakan Shalat Ketika Takbiratul Ihram dan Setelah Takbiratul Ihram
}

\author{
Suhadi, M. Si ${ }^{{ }^{*}}$, Miftahul Jannah ${ }^{1}$ \\ ${ }^{1}$ Program Studi Pendidikan Fisika, Universitas Islam Negeri Raden Fatah Palembang, \\ Palembang 30126, Indonesia \\ *e-mail:Suhadi@radenfatah.ac.id
}

\begin{abstract}
Abstrak
Penelitian ini dimaksudkan 1) untuk memperoleh informasi tentang gerakan shalat ketika takbiratul ihram dan setelah takbiratul ihram berdasarkan konsep fisika mengenai analisis torsi $\overrightarrow{\boldsymbol{\tau}}$ 2) untuk mengetahui nilai torsi $\overrightarrow{\boldsymbol{\tau}}$ dalam gerakan shalat ketika takbiratul ihram dan setelah takbiratul ihram. Penelitian ini menggunakan jenis penelitian deskriptif analisis yaitu suatu metode yang berfungsi untuk mendeskripsikan. Teknik analisis datamenggunakan operasi matematika yang disebut dengan hasil kali vektor (vector product) atau hasil kali silang (cross product) yang di fokuskan pada posisi gerakan shalat saat mengangkat tangan ketika takbiratul ihram dan setelah takbiratul ihram rumus torsi yang didapat dari sumber buku. Pada gerakan

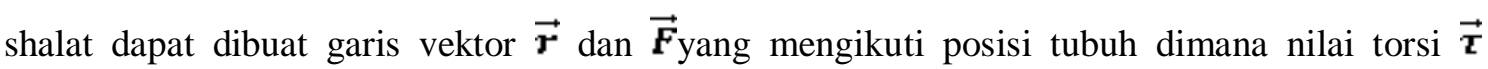
dihasilkan dari hasil kalivektor $\overrightarrow{\boldsymbol{r}}_{\text {dan }} \overrightarrow{\boldsymbol{F}}$. Penelitian menunjukkan hasil dari dua analisis pada gerakan shalat ketika takbiratul ihram dan setelah takbiratul ihram menghasilkan nilai torsi $\overrightarrow{\boldsymbol{\tau}}$ yang sama dan menunjukkan keadaan seimbang.
\end{abstract}

Kata Kunci: Shalat, Torsi, Keseimbangan

\section{Torsi Analysis Following The Prayer Pattern When Takbiratul Ihram and After Takbiratul Ihram}

\begin{abstract}
This research is intended 1) to obtain information about the movement of the prayer when takbiratul ihram and after takbiratul ihram based on the physics concept of torque analysis $\overrightarrow{\boldsymbol{\tau}} 2$ ) to determine the torque value $\overrightarrow{\boldsymbol{\tau}}$ in the movement of prayer when takbiratul ihram and after takbiratul ihram. This research uses descriptive analysis type of research which is a method that serves to describe. Data analysis techniques use mathematical operations called vector products or cross products that are focused on the position of the prayer movements when raising hands when takbiratul ihram and after takbiratul ihram torque formula obtained from the source book. In the prayer movement can be made vector lines $\overrightarrow{\boldsymbol{r}}$ and $\overrightarrow{\boldsymbol{F}}$ that follow the position of the body where the torque $\overrightarrow{\boldsymbol{\tau}}$ value is generated from the results of the cross vector $\overrightarrow{\boldsymbol{r}}$ and $\overrightarrow{\boldsymbol{F}}$. Research shows the results of two analyzes of the prayer movements when takbiratul ihram and after takbiratul ihram produce the same torque value $\overrightarrow{\boldsymbol{\tau}}$ and show a balanced state
\end{abstract}

Keywords: Prayers, Torques, Balance 


\section{PENDAHULUAN}

Menurut Rahman (1992), dalam Al-Qur'an diungkapkan bahwa Sains atau Ilmu Pengetahuan dan Al-Qur'an merupakan dua aspek kebenaran yang sama dan tidak ada pertentangan diantara keduanya. Wahyu pertama Al-Qur'an yang diturunkan kepada Nabi Muhammad SAW pun memerintahkan kepada umat islam supaya menuntut ilmu pengetahuan. Ilmu pengetahuan alam sendiri pada umumnya diartikan sebagai ilmu yang mempelajari tentangsusunan benda serta perkembangannya, sedang ilmu alam (Fisika) menyelidiki terkait fenomena-fenomenanya.

Al-Qur'an telah menunjukkan dimensi baru terhadap studi mengenai fenomena alam dan ilmu pengetahuan yang ada di alam ini. Terkait dengan ilmu pengetahuan bahwa ilmu alam (Fisika) juga merupakan ilmu pengetahuan alam yang dalam suatu kajiannya sangat erat berhubungan dengan suatu konsep torsi.Momen gaya (torsi) adalah sebuah besaran yang menyatakan besarnya gaya yang bekerja pada sebuah benda sehingga mengakibatkan benda tersebut berotasi. Momen gaya (torsi) merupakan besaran vektor yang memiliki nilai dan arah.

Shalat adalah suatu ibadah yang meliputi ucapan dan peragaan tubuh yang khusus, dimulai dengan takbir dan diakhiri dengan salam. Bagi setiap muslim shalat adalah sebuah kewajiban yang harus dilakukan sesuai dengan petunjuk Al-Qur'an dan Sunnah. Dalam ibadah ini, terjadi komunikasi ruhaniah antara muslim dengan pencipta-Nya tanpa tabir apapun, suatu bentuk dialog antara ruh yang menempati jasmani dan Zat Yang Maha Tinggi. Gerakan shalat terdiri dari berdiri, mengangkat kedua tangan ketika takbiratul ihram, kedua tangan disedekapkan pada dada, ruku', i'tidal, sujud, duduk diantara dua sujud, salam.

Shalat dalam kaitannya dengan materi torsi adalah menganalisis gerakan yang dilakukan pada shalat yang membentuk garis vektor $\overrightarrow{\boldsymbol{r}}$ dan $\overrightarrow{\boldsymbol{F}}$ yang mengikuti posisi tubuh dimana nilai torsi $\overrightarrow{\underline{\tau}}$ dihasilkan dari hasil kali vektor $\overrightarrow{\boldsymbol{r}}$ dan $\overrightarrow{\boldsymbol{F}}$.

Berdasarkan penjelasan diatas peneliti tertarik untuk meneliti tentang analisis torsi mengikuti pola gerakan shalat ketika mengangkat tangan ketika takbiratul ihram dan setelah takbiratul ihram (kedua tangan disedekapkan pada dada) yang menghasilkan nilai torsi yang memenuhi pola gerakan tersebut. Dalam penelitian ini peneliti membahas gerakan shalat yang dilakukan oleh manusia normal atau non disabilitas.

\section{TINJAUAN PUSTAKA}

\section{A. Shalat}

Syariat shalat sudah diajarkan kepada umat Nabi Ibrahim, meski penyempurnaan ajaran itu disampaikan oleh Nabi Muhammad SAW. Ketika Nabi Muhammad SAW mi'raj ke langit, beliau menerima langsung perintah dari Allah SWT tentang kewajiban shalat. Kita, umat beliau di akhir zaman ini, tinggal melaksanakan syariat yang sudah demikian rinci, tanpa menambah dan menguranginya. Inilah jalan selamat yang dibutuhkan manusia untuk kebahagiaan dunia dan akhirat. Demikianlah akhirnya Islam menyebar luas ke seluruh penjuru bumi dengan izin Allah SWT (Sagiran, 2014: 3-4).

\section{B. Gerakan Shalat}

Menurut bahasa, shalat mempunyai arti berdo'a untuk kebaikan. Sedangkan menurut istilah ahli fiqh, shalat adalah ucapan dan perbuatan yang dimulai dengan takbir dan diakhiri dengan salam dengan syarat-syarat tertentu. Shalat adalah amal perbuatan manusia yang pertama kali akan dihisab di hari Kiamat.

Mendirikan shalat ialah berharap hati kepada Allah sebagai ibadah, dengan penuh kekhusyukan dan keikhlasan di 
dalam beberapa perkataan dan perbuatan yang dimulai dengan takbir dan diakhiri dengan salam serta menurut syarat-syarat dan rukun-rukun yang telah ditentukan. Dalam shalat terdapat fardhu-fardhu dan rukun-rukun yang shalat itu sendiri merupakan rangkaian darinya, hingga jika rangkaian fardhu-fardhu tersebut dikerjakan tidak berurutan, maka perbuatan tersebut tidak diterima oleh syari'at sebagai shalat.

\section{Manfaat Shalat}

Manfaat shalat menurut referensi normatif Al-Qur'an merupakan manfaat utuh dan orisinil. Dikatakan utuh, karena shalat merupakan ibadah mahdlah yang diperintahkan tanpa keterlibatan manusia sama sekali, sehingga urgensinya pun tidak berdasarkan rasionalisasi manusia, melainkan dari-Nya. Sedangkan pengertian orisinil diambil dari kedudukan Al-Qur'an dalam Islam adalah sebagai sentral dan pijakan ajaran. Bila diklasifikasikan, manfaat shalat terbagi menjadi 2 macam, pertama shalat dapat memberikan kontribusi positif bagi pelakunya untuk dapat meningkatkan spiritualisasi dan keberagaman. Dalam hal ini, shalat merupakan kendaraan untuk mendekatkan hamba dengan Tuhan melalui peningkatan kualitasnya. Kedua, shalat dapat menjadi jembatan bagi hamba untuk dapat menempuh hubungan harmonis dengan yang lain. Dengan shalat, hamba bisa melakukan komunikasi produktif karena seseorang meninggalkan hal-hal yang dibenci dan kemungkaran. Dengan shalat, manusia bisamencapai derajat keyakinan yang dimahkotai ketenangan. Manusia tersebut akan berbeda dengan orang-orang yang tidak melaksanakan shalat.

\section{Torsi}

Torsi atau torque yang datang dari bahasa Latin yang berarti "untuk memutir" bisa diartikan secara bebas sebagai aksi memutar atau memutir dari gaya. Gambar 2.1a memperlihatkan penampang benda yang bebas berotasi terhadap sumbu yang melalui $O$ dan tegak lurus terhadap penampang. Gaya $\overrightarrow{\boldsymbol{F}}$ diberikan pada titik $P$, yang posisi relatifnya terhadap Odidefinisikan oleh vektor posisi $\overrightarrow{\boldsymbol{r}}$. Arah vektor $\overrightarrow{\boldsymbol{F}}$ dan $\overrightarrow{\boldsymbol{r}}$ membuat sudut $\boldsymbol{\theta}_{\text {satu sama lain. (Untuk }}$ penyederhanaan, kita hanya mempertimbangkan gaya yang tidak mempunyai komponen paralel terhadap sumbu rotasi; jadi sumbu $\overrightarrow{\boldsymbol{F}}$ berada pada bidang halaman ini).

Untuk menentukan bagaimana $\vec{F}$ menghasilkan rotasi suatu benda terhadap sumbu rotasi, kita selesaikan $\overrightarrow{\boldsymbol{F}}$ dalam dua komponen (Gambar 2.1b). Salah satu komponen, disebut komponen radial $\boldsymbol{F}_{\boldsymbol{r}}$ mengarah sepanjang $\overrightarrow{\boldsymbol{r}}$. Komponen ini tidak menyebabkan rotasi, karena komponen tersebut bekerja sepanjang garis yang diperpanjang melewati O.(Jika anda tarik pintu paralel terhadap bidang pintu, anda tidak memutar pintu). Komponen lain $\overrightarrow{\boldsymbol{F}}$, disebut komponen tangensial $\boldsymbol{F}_{\boldsymbol{t}}$, tegak lurus terhadap $\overrightarrow{\boldsymbol{r}}$ dan mempunyai magnitudo $\boldsymbol{F}_{\boldsymbol{t}}=\boldsymbol{F} \boldsymbol{s i n} \boldsymbol{\theta}$. Komponen ini menyebabkan rotasi. (Jika anda menarik pintu tegak lurus terhadap bidangnya, anda dapat merotasi pintu). Kemampuan $\vec{F}$ untuk merotasi benda tidak hanya bergantung pada magnitudo komponen tangensialnya $\boldsymbol{F}_{\boldsymbol{t}}$ tetapi juga pada sejauh apa dari $O$ gaya yang digunakan. Untuk melingkupi kedua faktor ini, kita definisikan sebuah kuantitas yang disebut torsi $\tau$ sebagai perkalian dua faktor dan ditulis sebagai :

$$
\tau=\boldsymbol{r} \boldsymbol{F} \sin \theta
$$

dua cara yang setara dengan perhitungan torsi adalah

$$
\begin{aligned}
\tau=\boldsymbol{r} F \sin \theta=\boldsymbol{r} F_{t} \\
\text { dan } \\
\tau=\boldsymbol{r} F \sin \theta=\boldsymbol{r}_{\perp} F
\end{aligned}
$$




\section{Analisis Torsi Mengikuti...Jupiter... Vol 1 No 2...Februari 2020...1-10 \\ Suhadi, Miftahul Jannah}

di mana $\boldsymbol{r}_{\perp}$ merupakan jarak tegak lurus antara sumbu rotasi pada Odan garis perpanjangan yang melalui vektor $\overrightarrow{\boldsymbol{F}}$ (Gambar 2.1c). Perpanjangan garis tersebut disebut garis kerja (line of action) $\overrightarrow{\boldsymbol{F}}$ dan $\overrightarrow{\boldsymbol{r}}_{\perp}$ disebut lengan momen (moment arm) $\overrightarrow{\boldsymbol{F}}$. Gambar $2.1 \mathrm{~b}$ memperlihatkan bahwa kita dapat menggambarkan $\overrightarrow{\boldsymbol{r}}$, magnitudo $|\overrightarrow{\boldsymbol{r}}|$ sebagai lengan momen komponen gaya $F_{t}$.
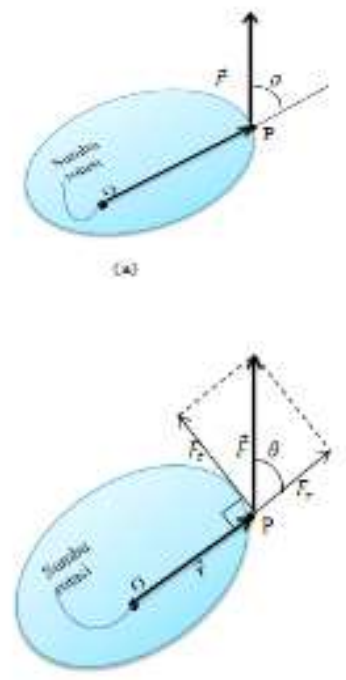

(b)

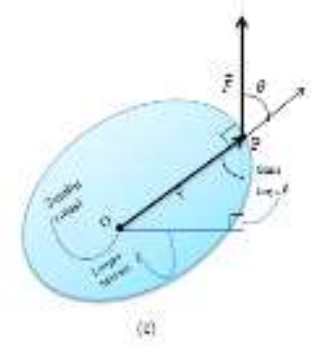

Gambar 2.1 (a) Sebuah gaya $\overrightarrow{\boldsymbol{F}}$ bekerja pada titik Ppada benda tegar yang bebas berotasi terhadap sumbu yang melalui $O$ : sumbu tegak lurus terhadap bidang penampang yang diperlihatkan di sini. (b) Torsi karena gaya ini adalah $\boldsymbol{r} \boldsymbol{F} \boldsymbol{s i n} \boldsymbol{\theta}$. Kita dapat juga menulisnya sebagair $\boldsymbol{F}_{\mathrm{t}}$ dengan $\boldsymbol{F}_{\mathrm{t}}$ adalah komponen tangensial $\vec{F}$. (c) Torsi dapat juga ditulis sebagai $\boldsymbol{r}_{\perp} \boldsymbol{F}$ dengan $\boldsymbol{r}_{\perp}$ adalah lengan momen $\vec{F}$
Jika dua atau lebih gaya bekerja pada suatu benda kaku, seperti gambar 2.2 masing-masing gaya cenderung berotasi terhadap sumbu $O$. Pada contoh ini $\boldsymbol{F}_{2}$ cenderung membuat benda berotasi searah jarum jam dan $\boldsymbol{F}_{\mathbf{1}}$ cenderung membuatnya berotasi berlawanan arah jarum jam. Kita gunakan kesepakatan bahwa tanda torsi yang dihasilkan dari sebuah gaya adalah negatif jika arahnya berlawanan arah jarum jam dan positif jika searah jarum jam.sebagai contoh pada gambar 2.2 torsi yang dihasilkan dari $\boldsymbol{F}_{\mathbf{1}}$ yang memiliki lengan momen $\boldsymbol{d}_{\mathbf{1}}$, adalah negatif serta sama dengan $-\boldsymbol{F}_{\mathbf{1}} \boldsymbol{d}_{\mathbf{1}}$ torsi dari $\boldsymbol{F}_{\mathbf{z}}$ adalah positif serta sama dengan $+\boldsymbol{F}_{\mathbf{Z}} \boldsymbol{d}_{\mathbf{2}}$. Jadi torsi netto terhadap $O$ adalah

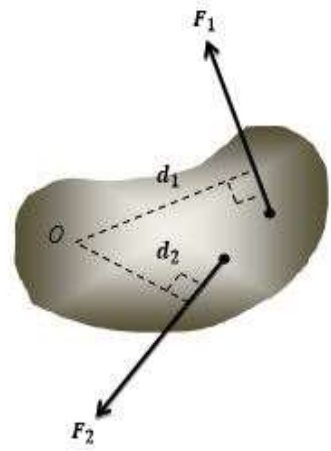

Gambar 2.2 Gaya $\boldsymbol{F}_{1}$ membuat benda berotasi berlawanan arah jarum jam terhadap $O$, dan $\boldsymbol{F}_{2}$ membuatnya berotasi searah jarum jam

Torsi tidak boleh tertukar dengan gaya. Gaya dapat menyebabkan perubahan dalam gerak linier, seperti yang dijelaskan oleh Hukum Gerak Newton II. Gaya juga dapat menyebabkan perubahan dalam gerak rotasi, tetapi efektivitas gaya itu dalam menyebabkan perubahan ini bergantung pada gaya dan lengan momen dari gaya itu. Gabungan inilah yang disebut torsi. Torsi memiliki satuan gaya kali panjang dalam SI N.m (Newton-meter).

Dengan demikian, dua persyaratan agar benda menjadi setimbang adalah sebagai berikut : 
1. Jumlah vektor semua gaya eksternal yang bekerja pada benda harus nol

2. Jumlah vektor semua torsi eksternal yang bekerja pada benda, diukur di sekitar titik yang mungkin manapun, juga harus nol

\section{BAHAN DAN METODE}

Pengkajian tentang analisis torsi pada gerakan shalat ketika takbiratul ihram dan setelah takbiratul ihram. Dilaksanakan pada bulan Juli 2019 di rumah dan kampus Universitas Islam Negeri (UIN) Raden Fatah Palembang.

Teknik analisis data pada penelitian ini menggunakan operasi matematika yang disebut dengan hasil kali vektor (vector product) atau hasil kali silang (cross product) yang di fokuskan pada posisi gerakan shalat saat mengangkat

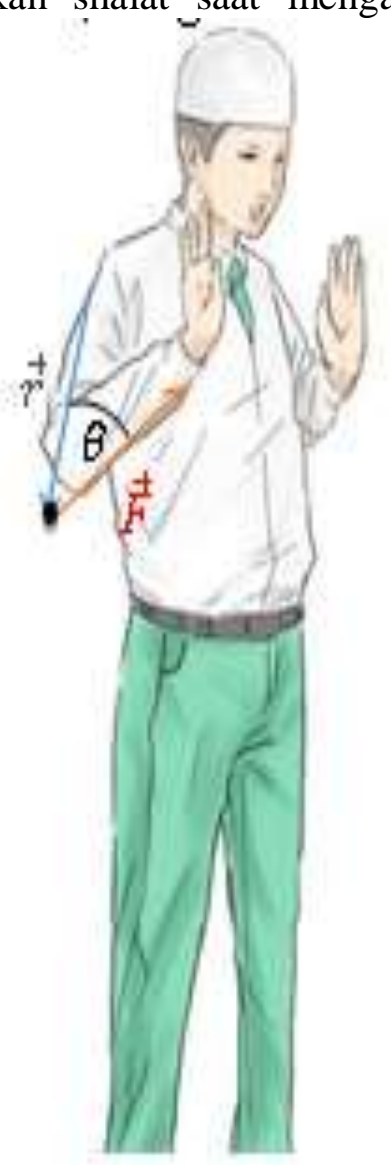

tangan ketika takbiratul ihram dan setelah takbiratul ihram (kedua tangan disedekapkan pada dada).

\section{HASIL DAN PEMBAHASAN}

Diketahui :

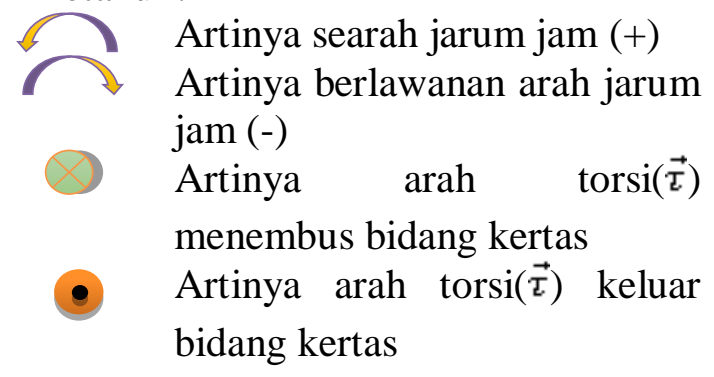

a. Analisis 1, tangan ketika takbiratul ihram

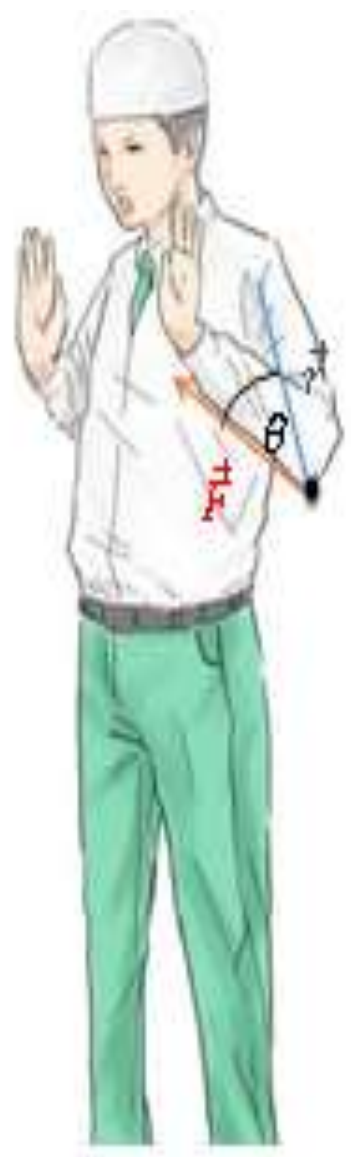


1) Tangan Kanan

$\tau=\vec{r} \times \vec{F}$

$\tau=-\left(\vec{r}_{1} \vec{F}_{1} \sin \theta\right)$ (keluar bidang kertas)

2) Tangan Kiri

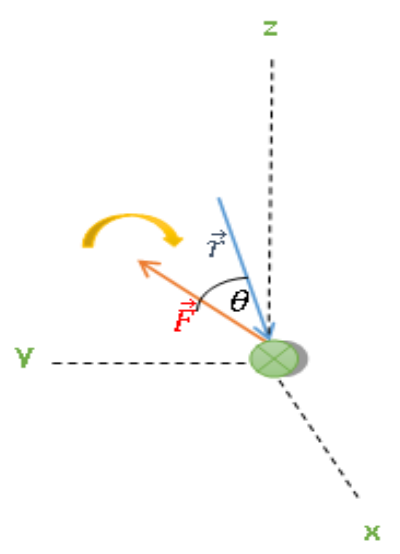

$\tau=\vec{r}_{2} \vec{F}_{2} \sin \theta$ (menembus bidang kertas)

Menganalisis Torsi ( $\tau$ ) dengan $\theta=180^{\circ}-30^{\circ}$ sebagai sudut yang dibentuk oleh tangan ketika takbiratul ihram.

a. $\theta=180^{\circ}$

$\tau=\vec{r} \times \vec{F}$

$\tau=\vec{r} \vec{F} \sin \theta$

$\tau=\vec{r} \vec{F} \sin 180^{\circ}$

$\tau=\vec{r} \vec{F}(0)$

$\tau=0$

b. $\theta=150^{\circ}$

$\tau=\vec{r} \times \vec{F}$

$$
\begin{aligned}
\tau & =\vec{r} \vec{F} \sin \theta \\
\tau & =\vec{r} \vec{F} \sin 150^{\circ} \\
\tau & =\vec{r} \vec{F}\left(\frac{1}{2}\right) \\
\tau & =\frac{1}{2} \vec{r} \vec{F}
\end{aligned}
$$

c. $\theta=135^{\circ}$

$\tau=\vec{r} \times \vec{F}$

$\tau=\vec{r} \vec{F} \sin \theta$

$\tau=\vec{r} \vec{F} \sin 135^{\circ}$

$\tau=\vec{r} \vec{F}\left(\frac{1}{2} \sqrt{2}\right)$

$v=\frac{1}{2} \sqrt{2} \vec{r} \vec{F}$

d. $\theta=120^{\circ}$

$\tau=\vec{r} \times \vec{F}$

$\tau=\vec{r} \vec{F} \sin \theta$

$\tau=\vec{r} \vec{F} \sin 120^{\circ}$

$\tau=\vec{r} \vec{F}\left(\frac{1}{2} \sqrt{3}\right)$

$\tau=\frac{1}{2} \sqrt{3} \vec{r} \vec{F}$

e. $\theta=90^{\circ}$

$\tau=\vec{r} \times \vec{F}$

$\tau=\vec{r} \vec{F} \sin \theta$

$\tau=\vec{r} \vec{F} \sin 90^{\circ}$

$\tau=\vec{r} \vec{F}(1)$

$\tau=\vec{r} \vec{F}$

f. $\theta=60^{\circ}$

$\tau=\vec{r} \times \vec{F}$

$\tau=\vec{r} \vec{F} \sin \theta$

$\tau=\vec{r} \vec{F} \sin 60^{\circ}$

$\tau=\vec{r} \vec{F}\left(\frac{1}{2} \sqrt{3}\right)$

$\tau=\frac{1}{2} \sqrt{3} \vec{r} \vec{F}$

g. $\theta=45^{\circ}$

$\tau=\vec{r} \times \vec{F}$

$\tau=\vec{r} \vec{F} \sin \theta$

$\tau=\vec{r} \vec{F} \sin 45^{\circ}$ 


$$
\begin{aligned}
\tau & =\vec{r} \vec{F}\left(\frac{1}{2} \sqrt{2}\right) \\
\tau & =\frac{1}{2} \sqrt{2} \vec{r} \vec{F} \\
\theta & =30^{\circ} \\
\tau & =\vec{r} \times \vec{F} \\
\tau & =\vec{r} \vec{F} \sin \theta \\
\tau & =\vec{r} \vec{F} \sin 30^{\circ} \\
\tau & =\vec{r} \vec{F}\left(\frac{1}{2}\right) \\
\tau & =\frac{1}{2} \vec{r} \vec{F}
\end{aligned}
$$

h. $\theta=30^{\circ}$

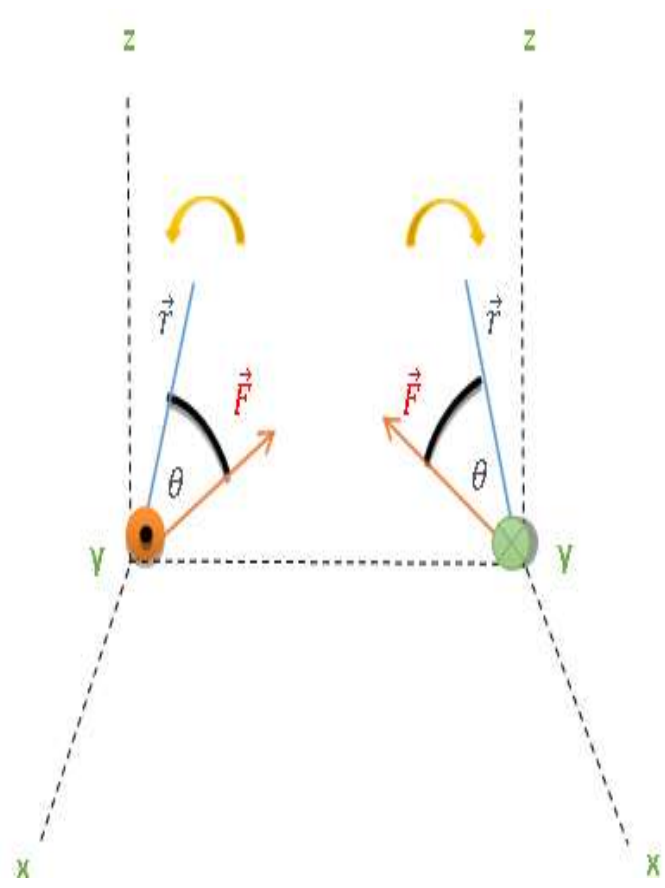

$\sum \vec{\tau}=0$

$\sum \vec{\tau}_{\text {kanan }}+\sum \vec{\tau}_{k i r i}=0$

$-\left(\vec{r}_{1} \vec{F}_{1} \sin \theta\right)+\vec{r}_{2} \vec{F}_{2} \sin \theta=0$

$-\vec{r}_{1} \vec{F}_{1} \sin \theta+\vec{r}_{2} \vec{F}_{2} \sin \theta=0$ b. Analisis 2, setelah takbiratul ihram (kedua tangan disedekapkan pada dada)

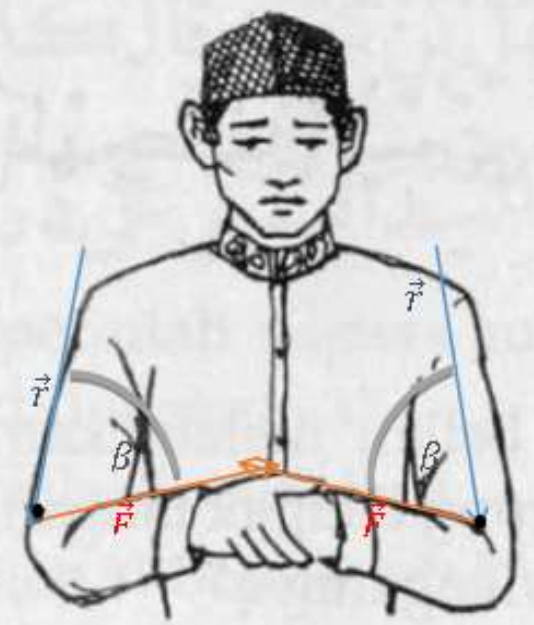

1) Tangan Kanan

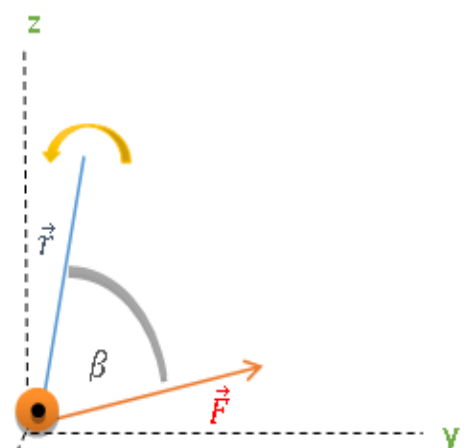

$$
\tau=\vec{r} \times \vec{F}
$$

$\tau=-\left(\vec{r}_{1} \vec{F}_{1} \sin \beta\right)$ (keluar bidang kertas) 
2) Tangan Kiri
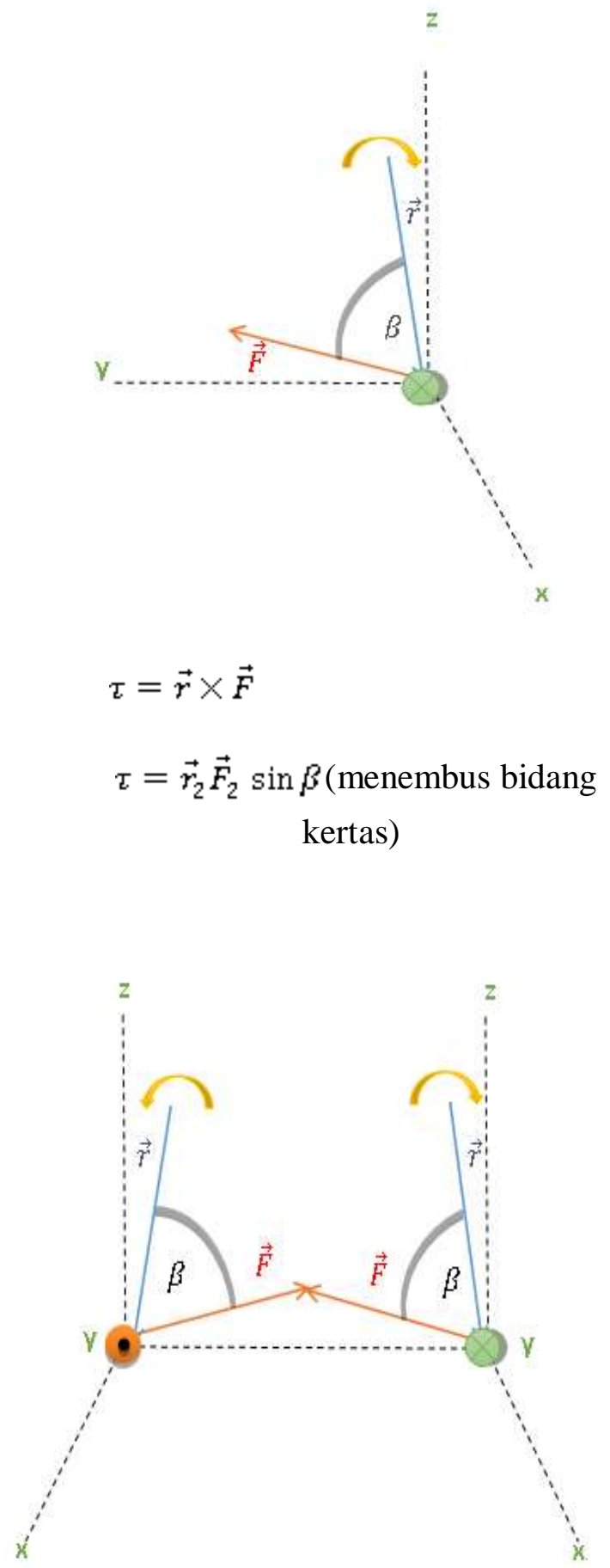

$\sum \vec{\tau}=0$

$\sum \vec{\tau}_{\text {kanan }}+\sum \vec{\tau}_{k i r i}=0$

$-\left(\vec{r}_{1} \vec{F}_{1} \sin \beta\right)+\vec{r}_{2} \vec{F}_{2} \sin \beta=0$

$-\vec{r}_{1} \vec{F}_{1} \sin \beta+\vec{r}_{2} \vec{F}_{2} \sin \beta=0$

\section{PEMBAHASAN}

Pada analisis torsi yang mengikuti pola pada gerakan shalat ketika takbiratul ihram dan setelah takbiratul ihram (kedua tangan disedekapkan pada dada) yang menghasilkan nilai torsi dengan memenuhi pola gerakan tersebut telah diteliti dan diketahui bahwa gerakan shalat dapat dibuat garis vektor $\overrightarrow{\boldsymbol{r}}$ dan $\vec{F}$ yang mengikuti posisi tubuh saat takbiratul ihram dan setelah takbiratul ihram (kedua tangan disedekapkan pada dada) yang benar menurut fiqih, dimana nilai torsi $\overrightarrow{\boldsymbol{\tau}}$ dihasilkan dari hasil kali vektor $\overrightarrow{\boldsymbol{r}}$ dan $\overrightarrow{\boldsymbol{F}}$, diketahui pula arah torsi dan arah rotasi gerakan shalat yang mengikuti posisi tubuh ketika takbiratul ihram dan setelah takbiratul ihram (kedua tangan disedekapkan pada dada). Arah torsi ditentukan dengan menggunakan kaidah tangan kanan dan arah rotasi nya menggunakan arah jarum jam yang telah ditentukan tanda yang dihasilkan sebelumnya.

Peneliti melakukan dua analisis, analisis pertama pada tangan ketika takbiratul ihramdan analisis kedua setelah takbiratul ihram(kedua tangan disedekapkan pada dada) dilakukan dengan menganalisis masing-masing tangan kiri dan kanan untuk mendapatkan nilai torsinya menggunakan rumus pada persamaan 5 .

Setelah mendapatkan vektor torsi $\overrightarrow{\mathbf{\tau}}$ dengan menggunakan operasi matematika yang disebut dengan hasil kali vektor (vector product) atau hasil kali silang (cross product), kemudian didapatkan arah torsi $\overrightarrow{\mathbf{\tau}}$ denganhasil tangan kanan keluar bidang kertas dan torsi $\overrightarrow{\boldsymbol{\tau}}$ bernilai negatif $(-)$ karena berlawanan arah jarum jam, sedangkan tangan kiri menembus bidang kertas dan torsi $\overrightarrow{\mathbf{\tau}}$ bernilai positif (+) karena searah jarum jam. Menganalisis kedua tangan untuk menentukan nilai torsinya, saat kedua tangan bekerja dibutuhkan 
keseimbangan. Untuk mencapai keseimbangan adalah gaya netto yang bekerja pada benda haruslah nol.Untuk rotasi pada sumbu yang tetap, kondisi yang dibutuhkan untuk mencapai keseimbangan rotasional adalah bahwa torsi netto pada semua sumbunya haruslah nol.

Setelah dianalisis hasil dari resultan torsi:

$$
\begin{gathered}
\sum \overrightarrow{\boldsymbol{\tau}}=0 \\
\sum \overrightarrow{\boldsymbol{\tau}}_{\text {kanan }}+\sum \overrightarrow{\boldsymbol{\tau}}_{\text {kiri }}=0
\end{gathered}
$$

Ini menjelaskan bahwa hasil torsi $\overrightarrow{\boldsymbol{z}}$ dari kedua tangan saat takbiratul ihram dan setelah takbiratul ihram (kedua tangan disedekapkan pada dada) adalah setimbang, karena berdasarkan syarat keadaan setimbang adalah:

1. Jumlah vektor semua gaya eksternal yang bekerja pada benda harus nol

2. Jumlah vektor semua torsi eksternal yang bekerja pada benda, diukur di sekitar titik yang mungkin manapun, juga harus nol

Analisis yang dilakukan pada saat tangan melakukan gerakan takbiratul ihram dilanjutkan dengan menghitung sudut-sudut istimewa yang terbentuk dari gerakan takbiratul ihram, yakin sudut $\theta=180^{\circ}-30^{\circ}$. Setelah dihitung dengan sudut istimewa didapatkan hasil torsi $\vec{\tau}$ dari kedua tangan yang bekerja adalah 0, ini membuktikan bahwa keadaan saat takbiratul ihram dan setelah takbiratul ihram menjelaskan keadaan seimbang.

Apabila di hubungkan dengan shalat, istilah shalat menunjukkan bahwa dalam shalat itu terdapat antara lain :

1. Shalat adalah salah satu bantuan terbesar dalam mencapai kebahagiaan di dunia dan akhirat. Juga dalam menghadang semua kerusakan dunia dan akhirat, karena dengan shalatlah kemungkaran dan perbuatan itu dilarang. Shalat akan memotivasi individu untuk lebih menjernihkan hati dan menghapus segala penyakit kejiwaan dan dengki hati, shalat dapat menjadi jembatan bagi hamba untuk dapat menempuh hubungan harmonis dengan yang lain.

Dengan shalat, hamba bisa melakukan komunikasi produktif karena seseorang meninggalkan halhal yang dibenci dan kemungkaran. Manusia bisa mencapai derajat keyakinan yang dimahkotai ketenangan jiwa, ketenangan jiwa adalah keadaan seseorang dalam keseimbangan hidup, orang yang mampu mengkondisikan dirinya dimanapun ia berada, baik dengan lingkungan maupun manusia sekitarnya. Mampu menjaga pikiran, perasaan dan perbuatan, tidak berprasangka buruk, tidak gelisah, penuh pertimbangan, dan sikap tenang.

2. Shalat adalah hubungan antara manusia dengan Tuhan, seseorang berdiri khusyu' dan merendahkan diri dihadapan Allah SWT Yang Maha Agung lagi Maha Kuasa atas segala sesuatu yang mengatur seluruh langit dan bumi di dalam hidup ini. Pelepasan total dengan segala kesibukan, problematika dan kegundahan hidup, tidak memikirkannya ketika shalat berdiri dihadapan Rabb-nya dengan totalitas khusyu' pada gilirannya akan melahirkan reaksi total dengan kelegaan jiwa dan ketenangan pikiran.

Sesungguhnya shalat merupakan sarana paling penting yang dapat menyisakan ketentraman dalam jiwa dan menebarkan relaksasi pada syaraf. Arti dari kata "pelepasan total' adalah melupakan sejenak tentang duniawi ketika melaksanakan shalat. Serta dapat memberikan kontribusi positif bagi pelakunya 
untuk dapat meningkatkan spiritualisasi dengan tawakkal kepada Allah SWT, tawakkal adalah membebaskan hati dari ketergantungan kepada selain Allah SWT dan menyerahkan segala keputusan hanya kepada Allah SWT.

Orang-orang yang tidak melaksanakan shalat dan mengerjakan shalat secara asal-asalan, hanya sekedar sebagai kewajiban, tidak akan pernah bisa membentuk jati diri yang teratur, seimbang, dan memiliki hubungan yang harmonis dengan dirinya sendiri, lingkungannya, dan Ilahi-nya. Oleh karena itu Allah SWT mengecualikan mereka dengan ketidakstabilan jiwa.

Sehingga dalam hal ini, hasil torsi $\overrightarrow{\boldsymbol{\tau}}$ dari kedua tangan saat takbiratul ihram dan setelah takbiratul ihram (kedua tangan disedekapkan pada dada) adalah setimbangdan hasil gaya yang bekerja adalah nol, berhubungan orang yang mengerjakan shalat mempunyai jiwa yang stabil dan tenang. Modal utama yang menjadikan kehidupan seimbang adalah peningkatan dimensi spiritual berupa shalat. Sehingga sudah jelas bahwa saat shalat berdiri dihadapan Rabb-nya dengan totalitas khusyu' pada gilirannya akan melahirkan reaksi total dengan kelegaan jiwa dan ketenangan pikiran.

\section{KESIMPULAN}

Konsep fisika yang digunakan dalam analisis gerakan shalat ketika takbiratul ihram dan setelah takbiratul ihram adalah analisis torsi yang akan menghasilkan nilai torsi dan keseimbangan. Arah torsi ditentukan dengan menggunakan kaidah tangan kanan dan arah rotasinya menggunakan arah jarum jam yang telah ditentukan tanda yang dihasilkan sebelumnya.Dari dua analisis yang dihasilkan dari gerakan shalat ketika takbiratul ihram dan setelah takbiratul ihram, menghasilkan nilai torsi yang sama dimana hasil tangan kanan keluar bidang kertas dan torsi $\overrightarrow{\mathbf{\tau}}$ bernilai negatif (-) karena berlawanan arah jarum jam, sedangkan tangan kiri menembus bidang kertas dan torsi $\overrightarrow{\boldsymbol{\tau}}$ bernilai positif (+) karena serah jarum jam. Hasil dari analisis kedua tangan yang bekerja secara bersamaan nilai torsinya sama dengan nol yang artinya menyatakan bahwa saat takbiratul ihram dan setelah takbiratul ihram adalah keadaan setimbang. Modal utama yang menjadikan kehidupan seimbang adalah peningkatan dimensi spiritual berupa shalat. Sehingga sudah jelas bahwa saat shalat berdiri dihadapan Rabb-nya dengan totalitas khusyu' pada gilirannya akan melahirkan reaksi total dengan kelegaan jiwa dan ketenangan pikiran.

\section{DAFTAR PUSTAKA}

Halliday. 2010. Fisika Dasar Edisi 7 Jilid 1. Jakarta: Erlangga

Ma'rufah, Yuanita. 2015. Manfaat Terhadap Kesehatan Mental Dalam AL-Qur'an, Skripsi Fakultas Ushuluddin Dan Pemikiaran Islam UIN Sunan Kalijaga. Yogyakarta.

Rumiyati. 2017. Nilai-Nilai Kesehatan Fisik Dan Mental Dalam Ibadah Shalat (Telaah Buku Mukjizat Gerakan Shalat Karya Sagiran), Skripsi Fakultas Ilmu Tarbiyah Dan Keguruan IAIN Salatiga. Salatiga

Sagiran. 2014. Mukjizat Gerakan Shalat. Jakarta: Qultum Media.

Serway. 2009. Fisika Untuk Sains Dan

Teknik. Jakarta: Salemba Teknika

Sugiyono. 2009. Metode Penelitian Kuantitatif, Kualitatif dan $R$ \& $D$. Bandung: Alfabeta. 